\title{
DETERMINANTS OF CORPORATE PROFITABILITY OF COMPANIES FROM CONSTRUCTION AND REAL ESTATE INDUSTRIES IN SELECTED EUROPEAN COUNTRIES
}

\author{
[Determinanty podnikové ziskovosti společností ze stavebního a realitního \\ průmyslu ve vybraných evropských zemích]
}

\author{
Nicole Škuláňová ${ }^{1}$ \\ ${ }^{1}$ Silesian University, School of Business Administration, Univerzitni nám. 1934/3, 73340 Karviná \\ Email: skulanova@opf.slu.cz.
}

\begin{abstract}
The basic economic rule in any business should be profit maximization and also each business entity establishes a company in order to generate profit from invested funds. So, profitability indicators have a significant position among the criteria of economic activity. Achieving profitability is influenced by a myriad of determinants. This study focuses on some external determinants. The subjects of the research are companies from eight European economies, which come from two sectors, namely construction and real estate activities, which are divided into twelve groups according to the NACE classification. The aim of the research is to use Generalized Method of Moments to find out whether selected determinants affect corporate profitability or not. The determinants are as follows: GDP growth rate, inflation rate, basic interest rate, unemployment rate, gross fixed capital formation. The research covers the period 2010-2018. In total, over 89,000 companies are surveyed. There is at least one main finding, namely the greatest influence on the level of profitability in the construction and real estate activities sectors has the basic interest rates of individual economies and that this effect is mostly negative.
\end{abstract}

Keywords: corporate profitability, GDP, gross fixed capital formation, inflation, interest rate, unemployment.

JEL classification: G32

Received: 1.10.2020; Reviewed: 3.11.2020; 9.12.2020; Accepted: 27.1.2021

\section{Introduction}

Profitability is one of the basic pillars of any business. The "rule of profit maximization" can be found in economic theories and in theories of corporate finance (along with liquidity and risk). From this, the significance of this variable for each firm can be deduced. Higher profits allow companies to renew and expand their capital not only in the form of tangible or intangible assets, but also in the form of human capital, innovation and streamlining of various business processes. All these things shape the company and help it achieve the highest profits.

Like everyone in our lives, profitability is influenced by a huge number of factors that come from the company's environment, from the characteristics of the industry and, of course, from the company's external environment. This research focuses on the last category of factors. The aim of the research is to use Generalized Method of Moments to find out whether selected determinants affect corporate profitability or not. The determinants are as follows: GDP growth rate, inflation rate, basic interest rate, unemployment rate and gross fixed capital formation. The subject of this research are companies operating in the construction industry and real estate activities originating from eight selected economies of Central and Eastern Europe. The motivation for the selection of these economies is the effort to expand knowledge in them, because, as the literature search shows, not many studies have been found for them. 
The main benefit of this research should be the dissemination of existing knowledge in this area, as will be shown in the following chapter, many studies dealing with this issue have not been found and at the same time most of them have focused on banking and insurance sector. Also, no studies containing all selected determinants were found, so there should be an expansion of knowledge regarding the impacts of selected determinants and at the same time selected economies. Last but not least, the examined sample of companies is unusually large, containing over 89,000 companies. These sectors will be examined at the level of twelve subsectors, so within each economy twelve panels and a total of ninety-six panels will be analyzed, which should show us at least in part what influences the formation of profitability in individual sub-sectors and economies.

This paper is organized as follows. Section 1 outlines earlier studies on the financial structure. Section 2 presents the research methodology, variables and provides a description of the industry and examined economies. Section 3 describes the results of the analysis of variable dependencies. Section 4 presents the conclusions.

\section{Literature overview}

Athanasoglou, Brissimis and Delis (2008) focused on the Greek banking sector during the period 1985-2001 and found that the profitability of banks is positively affected by the business cycle. Furthermore, the authors revealed that when the output of the economy above the trend, the coefficient doubles, on the contrary, if the output of the economy is below the trend, the coefficient is insignificant, which means that banks can isolate their performance in times when the economy is failing.

Dietrich and Wanzenried (2011) examined Swiss banks during the period 1999-2009, which was divided into a pre-crisis period until 2006 and a crisis period from 2007. The sample examined 372 commercial banks and was found that real GDP growth had a positive impact during the whole and pre-crisis period, but during the crisis period the effect was negative. Banks' profits thus appear to be pro-cyclical, given that demand for credit grows during economic growth and vice versa. The impact of the interest rate was positive on profitability during all these periods.

Ćurak, Poposki and Pepur (2012) analyzed sixteen Macedonian banks from 2005 to 2010, during which the banking system was consolidated. At the end of this period, eighteen banks and eight saving houses were operating on the market. Foreign owners also began to dominate here. The authors revealed that GDP growth has a positive effect on banks' economic activities, which is due to growing household savings and growing corporate demand for financing.

Mirzaei, Moore and Liu (2013) compared 1,929 banks from emerging (308) and seventeen Western European economies (1,621) during 1999-2008. The results showed that, regardless of the group to which the economy belongs, the GDP growth rate still has a positive impact on the level of profitability. In the case of inflation, a negative effect was demonstrated in advanced economies, but unfortunately in emerging economies the results were statistically insignificant, however, the coefficients also pointed to a possible negative impact.

Dietrich and Wanzenried (2014) analyzed a very large sample of 10,165 commercial banks from 118 countries during the period 1998-2012. The economies were divided into three groups according to income into low, middle and high-income economies. The authors found that for a sample of all countries, for low- and middle-income economies, inflation has a 
positive impact on debt levels. For high-income, there is a negative coefficient, which is unfortunately statistically insignificant. The development of the GDP growth rate was found to be negative in a sample of all countries and a statistically insignificant negative impact in low-income economies. On the other hand, in the middle- and high-income economies, they are positively affected by GDP developments.

Djalilov and Piesse (2016) also focused on the banking sector in the transition countries of Central and Eastern Europe during the years 2000-2013. The authors examined a panel of 275 commercial banks from sixteen transition economies, which were divided into early transition countries (e.g. CZ, SK, PL, HU, SI) and late transition countries (e.g. Armenia, Moldova, Kazakhstan). Unfortunately, the coefficients for GDP and the inflation rate were statistically insignificant, however, the coefficients indicated the direction in which these variables could affect profitability. For late transition countries, both variables have a positive impact, while for early transition countries, there is a positive impact of GDP and a negative impact of inflation on banks' profitability.

Zuidberg (2017) focused on 125 airports from Europe, the United States, Canada, Australia and New Zealand during the period 2010-2016. Among other things, this research analyzed the impact of GDP development on the level of profitability. As part of the analysis, the author created several panels - all commercial airports and all cargo airports, which were subdivided into European low-cost airports, Ryanair/easyJet, US low-cost airports and Southwest, airports with less than 10 million passengers, airports with more than 10 million passengers, to hub airports and non-hub airports. Unfortunately, almost all the results were statistically insignificant, but at least they showed us an indication of what impact the development of the economy could have on the level of profitability of these companies. Negative coefficients were found at European low-cost airports, Ryanair/easyJet, airports with more than 10 million passengers. The rest of the coefficients had a positive impact on the level of profitability.

Martins, Serra and Stevenson (2019) examined the behavior of 108 real estate banks, which came from the United States, the United Kingdom and Germany. These institutions were analyzed for the period 2000-2014. The authors divided the sample into several stages - the whole period, before the financial crisis until 2006 and during the financial crisis until 2010. The results showed that interest rates and GDP development had a positive impact on profitability for the whole and pre-crisis period and a negative impact during the crisis. period. Inflation showed a positive effect on the level of profitability in all these periods. The same relationships between the variables remained even though the authors divided the panels according to individual countries.

Vera-Gilves et al. (2020) examined 23 Ecuadorian private banks between 2002 and 2017. During this period, Ecuador was affected by two economic crises in 2009 and 2015, which affected the performance of the sector. The authors confirmed the positive effect of interest rates and GDP, and, conversely, the negative impact of inflation on profitability.

Le and Ngo (2020) dealt with the banking systems of twenty-three countries for the period 2002 to 2016. Unfortunately, the coefficients for the impact of GDP and inflation were both statistically insignificant, but at least they indicated a possible impact that would be negative.

In his research, Killins (2020) focused on the Canadian life insurance sector, in which he analyzed thirty-eight federally regulated domestic life insurers from 1996 to 2018. Among the 
macroeconomic variables that will be examined in this research, GDP development is represented here, whose coefficient showed a positive effect on the level of profitability.

Other authors such as Bourke (1989), Molyneux and Thornton (1992), Claessens, DemirgüçKunt and Huizinga (1998), Demirgüç-Kunt and Huizinga (1998), Bikker and $\mathrm{Hu}$ (2002), Albertazii and Gambacorta (2009) ), Bashir (2003), Flamini, McDonald and Schumacher (2009), Aliaga-Diaz and Olivero (2010), Pervan, Pervan and Guadagnino (2010), Akotey, Sackey and Amoah (2013), Gaganis, Hasan and Pasiouras (2013), Košak and Čok (2013), Almeida and Divino (2015) dealt with the banking or insurance sector and revealed the positive impact of GDP on the level of bank profitability. Their explanation has already been mentioned, namely that the demand for loans is associated with economic growth. Conversely, if the economy is in recession, the credit quality of banks is deteriorating. Of course, the development of GDP can also have a negative impact on the level of profitability, but there are not many such studies - Tan and Floros (2012) and Saona (2016).

Revell (1979), Bourke (1989), Molyneux and Thornton (1992), Perry (1992), Claessens, Demirgüç-Kunt and Huizinga (1998), Demirgüç-Kunt and Huizinga (1998), Albertazii and Gambacorta (2009) revealed positive the relationship between profitability and inflation. Many authors argue that the impact of inflation depends on whether inflation expectations are expected or not or only partially. If inflation is expected to rise, banks can adjust interest rates (increase) and thus increase their yields. It is also necessary to take into account whether banks' costs are rising faster than inflation. Of course, inflation can also have a negative impact on profitability, but there are not many such studies - Sufian and Chong (2008).

Bourke (1989), Molyneux and Thornton (1992), Claessens, Demirgüç-Kunt and Huizinga (1998), Demirgüç-Kunt and Huizinga (1998), Albertazii and Gambacorta (2009), Flamini, McDonald and Schumacher (2009) also dealt with impact of interest rates on profitability and all found a positive impact.

Unfortunately, the mentioned studies dealt with very different samples of countries, and therefore it is slightly difficult to create preconditions for this research on the basis of the search and then to compare its results with previous results. It will be an extension of knowledge rather than the comparison itself.

\section{Data and methodology}

The subject of this research are companies from eight economies from Central and Eastern Europe: the Czech Republic (CZ), Slovakia (SK), Poland (PL), Hungary (HU), Austria (AT), Slovenia (SI), Romania (RO), Bulgaria (BG). These economies belong to the so-called extended Visegrád Group. Austria, Slovenia, Romania and Bulgaria have been added, as these economies often belong to the original Visegrád Four, and at the same time representatives of these economies are very often present at the group's meetings. The companies fall into two branches - according to the NACE classification, these are section F - Construction and section $\mathrm{L}-$ Real estate activities. Industries are examined at the group level. According to the NACE classification, these groups are - 411 Development of building projects, 412 Construction of residential and non-residential buildings, 421 Construction of roads and railways, 422 Construction of utility projects, 429 Construction of other civil engineering projects, 431 Demolition and site preparation, 432 Electrical, plumbing and other construction installation activities, 433 Building completion and finishing, 439 Other specialized construction activities, 681 Buying and selling of own real estate, 682 Renting and operating of own or leased real estate and 683 Real estate activities on a fee or contract basis. In 
Figure 1 we can see the numbers of companies in individual economies and industry groups. These are all companies from the Orbis database, which includes medium, large and very large companies. A total of 89,544 companies have been tested. The individual time series come from the Orbis database (financial statements of companies), the World Bank database (GDP, inflation, unemployment, gross fixed capital formation), the database of central banks of selected economies (interest rate). The research period is 2010-2018.

The aim of the research is to use Generalized Method of Moments to find out whether selected determinants affect corporate profitability or not. The determinants are as follows: GDP growth rate, inflation rate, basic interest rate, unemployment rate and gross fixed capital formation. Partly on the basis of a literature search and partly on the basis of one's own assumptions, the following four research questions were formulated:

1. Economic development and gross fixed capital formation should have a positive impact on the level of profitability. (As if the economy is doing well, enterprises are usually doing well and demand for their products or services is growing due to rising disposable income of households or other firms.)

2. The inflation rate could also have a positive effect on the level of profitability. (Here is the connection with the real interest rate, which should fall as the inflation rate rises, which companies could use for further indebtedness.)

3. The reference interest rate should have a negative impact on the level of profitability. (As the lower the interest rate (and therefore the lower the cost of debt financing), the more room there is for companies to use debt financing, which brings additional resources for higher production and higher profits.)

4. The unemployment rate should also negatively affect the level of profitability. (As with the rise in unemployment, the demand for corporate products or services may decrease due to a decrease in household disposable income.)

At the beginning, it would be appropriate to analyze a bit the development of selected industries in individual economies. Figure 1 shows that most companies operate in Poland, the Czech Republic and Austria. There are over 10,000 companies in these economies, most of which belong to the Construction sector. Table 1 shows the annual production in construction in 2016 (latest available data). We see that Poland produces the most, followed by Austria and the Czech Republic.

Figure 1: Number of companies in individual subsectors in individual countries

\begin{tabular}{c|cccccccc} 
& AT & BG & CZ & HU & PL & RO & SK & SI \\
\hline 411 & 1596 & 136 & 430 & 447 & 3218 & 1022 & 24 & 132 \\
412 & 1165 & 1903 & 3868 & 1615 & 6572 & 3124 & 1317 & 358 \\
421 & 120 & 273 & 300 & 461 & 1374 & 587 & 124 & 82 \\
422 & 42 & 167 & 385 & 281 & 913 & 149 & 101 & 40 \\
429 & 36 & 275 & 68 & 96 & 374 & 120 & 109 & 51 \\
431 & 274 & 66 & 2797 & 204 & 520 & 107 & 279 & 38 \\
432 & 1985 & 357 & 1621 & 823 & 2795 & 1136 & 475 & 260 \\
433 & 1368 & 487 & 1357 & 205 & 1039 & 217 & 1141 & 204 \\
439 & 1379 & 382 & 752 & 368 & 1040 & 263 & 312 & 164 \\
681 & 987 & 513 & 153 & 1954 & 1722 & 553 & 100 & 117 \\
682 & 1722 & 1272 & 6385 & 1811 & 3563 & 1115 & 1504 & 249 \\
683 & 2684 & 325 & 1551 & 253 & 1940 & 240 & 832 & 129 \\
$\Sigma$ & 13358 & 6156 & 19667 & 8518 & 25070 & 8633 & 6318 & 1824 \\
\hline
\end{tabular}

Source: author's calculations based on data from Orbis database

The development of the construction industry is very similar in the monitored economies. In fact, with the exception of Austria, all the remaining economies have been hit by the financial crisis, which has affected the construction industry, which is a cyclical sector and thus 
responds to economic developments. In most economies, the sector did not recover strongly until 2015. However, in many of the following year, production fell, due to the end of funding from European funds, when it was at this time that the drawing of funds from the 2007-2013 programs ended. In most countries, the recovery has been helped by the recovery of the economy itself, which has led to an increase in household income. Also, in recent years, a new programming period 2014-2020 has begun, when economies can once again draw on European funding for the development of this sector. The Slovenian economy had a downturn at the beginning of the period, exacerbated by its own crisis, which was identical to that in the United States. The only exception is the Austrian construction sector, which, on the other hand, grew for most of the period under review. This growth was caused by the growth of the economy, and especially by investments in railway infrastructure. (European Construction Sector Observatory - Country profile)

Table 1: Annual production value of the construction industry in individual economies in 2016 (mil. euro)

\begin{tabular}{|c|c|c|c|c|c|c|c|}
\hline CZ & SK & PL & HU & AT & SI & BG & RO \\
\hline $25,788.4$ & $8,877.4$ & $57,494.4$ & $7,931.8$ & $46,387.9$ & $4,062.9$ & $5,916.2$ & $17,190.2$ \\
\hline
\end{tabular}

Source: statistics from web portal Statista.com

It would also be useful to mention at least one statistic relating to the Real Estate sector. Figure 2 is connected with this industry, in which we can see the development of the house price index during the observed period. This index measures the development of the price level of residential real estate. It is an index harmonized within the EU, and therefore its advantage is international comparability. As the construction industry has developed, so has this sector. In the figure we can see that until 2014/2015 the index decreased, as did production in construction. Only then did demand begin to grow in most economies, followed by supply growth. Most economies have also been supported by central banks, which have reduced mortgage rates, and governments in many economies have introduced subsidy and support programs to increase housing demand. In some economies, such as the Czech Republic, supply has lagged behind and is lagging behind demand due to excessive bureaucracy.

Figure 2: House price index

\begin{tabular}{l|ccccccccc} 
& 2010 & 2011 & 2012 & 2013 & 2014 & 2015 & 2016 & 2017 & 2018 \\
\hline CZ & 6,6 & $-5,5$ & $-3,1$ & $-1,4$ & 0,9 & 6,5 & 14,2 & 24,4 & 30 \\
SK & $-1,2$ & $-17,5$ & -8 & $-3,3$ & $-0,4$ & 7,8 & 14 & 19 & 21,3 \\
PL & $-7,2$ & $-6,4$ & -7 & $-7,6$ & $-6,8$ & -2 & 4,4 & 7,4 & 12,7 \\
HU & $-5,3$ & $-10,7$ & $-9,2$ & $-9,4$ & $-2,2$ & 14,8 & 33,6 & 43,9 & 45,5 \\
AT & 11,5 & 17,3 & 21,1 & 19,9 & 16,8 & 14,2 & 17,8 & 19,9 & 19,6 \\
SI & -3 & $-6,9$ & $-4,2$ & $-9,4$ & $-17,6$ & $-10,8$ & $-2,8$ & 12,5 & 22,5 \\
BG & $-10,6$ & $-32,4$ & $-16,7$ & $-9,3$ & $-2,7$ & 2 & 11,6 & 19,5 & 24 \\
RO & - & $-38,2$ & -23 & -17 & $-7,3$ & 0,5 & 6,7 & 15,6 & 18,6 \\
\hline
\end{tabular}

Source: statistics from Eurostat database

At the end of the subchapter, it would be worth mentioning the development in selected economies. At the beginning, it can be noted that the observed period was relatively rich in economic events. The beginning of the period is connected with the still lingering financial crisis of 2008/2009, which turned into a debt crisis in Europe, which was followed or in some countries accompanied by a global economic slowdown in 2012/2013. The latest event is the decline in global demand at the end of the period under review. In addition to these major joint events, economies have gone through other internal problems. In the following 
paragraphs, the development in the selected eight economies will be very briefly summarized, if the resulting coefficients are statistically significant, the economic development and its impact will be analysed in more detail.

Basically, selected economies can be divided into two groups: those that had serious economic problems and those that did not have economic problems or had minor economic problems. We can include Hungary, Romania and Slovenia in the first group. As a result of the financial crisis, the first two economies were forced to apply for an international loan in order to stabilize their economies. In the case of Hungary, the crisis was caused by the government's poor performance and the weakening of the forint against other currencies, which led to an increase in indebtedness. In Romania, a loan was needed to revive the credit market. The Slovenian government has not asked for financial assistance, although it has gone through a mortgage, real estate and banking crisis.

The second group of economies includes Poland, Bulgaria, the Czech Republic, Slovakia and Austria. The Polish economy is one of the few economies in the world that did not experience an economic downturn during this period. The Bulgarian and Slovak economies recovered very quickly from the financial crisis and grew throughout the period under review. The Czech Republic was hit by the financial crisis and recession in 2012/2013, however, the economy has recovered from both events and has been growing at a very high rate in recent years. The Austrian economy had to introduce a deposit guarantee as a result of the crisis, but greater measures were not needed.

\subsection{Methodology}

Several econometric methods can be used to determine how and whether selected determinants affect the level of profitability in companies. The Generalized Method of Moments, based on panel regression, will be used in this research. Panel regression is the most suitable method in this case, as the examined panels contain a huge number of companies, determinants and economies. However, simple panel regression - the least squares method is not suitable in this research, because determinants are represented only by macroeconomic time series, which can often be non-stationary. It is the stationarity of the time series that is a necessary condition for the least squares method. (Průcha 2014)

As mentioned, the Generalized Method of Moments (GMM) will be used, which has found its application mainly in the field of finance and eliminates the shortcomings of other possible methods that can be used in this case. (Jagannathan et al. 2002)

This model was characterized by Arellano and Bond (1991), then these authors collaborated with others and a number of studies were created on this model and its assumptions. The basic characteristics of the model are described in study by Roodman (2009). This study shows that the model is ideal for shorter time series; there is a linear functional relationship and fixed individual effects are present; the dependent variable on the left side of the equation is dynamic and depends on its lagged values; conversely, independent variables may not be strictly independent, suggesting that variables may be correlated with past and present errors; autocorrelation and heteroskedasticity (both of which cannot be tested in this method) should not be observed across individual observations. The method thus solves the endogeneity problem (correlation between the independent variable and the error term), which could occur in the least squares method. Ullah et al. (2018) add that this method uses certain internal tools that remove unobserved heterogeneity, simultaneity and dynamic endogeneity. These three phenomena are the sources of endogeneity. 
Ullah et al. (2018) further state that due to the fact that the GMM method cannot test the autocorrelation and heteroskedasticity of variables, as already mentioned, some tool is needed to tell us whether we can trust the model. There are several such tools, the Sargan test is used in this research, the essence of which is that if its value exceeds 0.05 , then the model is constructed correctly, and even if we change parameters slightly, we should get same results. The equation of the model looks like this:

$$
\begin{gathered}
\text { PROF F }_{\text {it }}=\alpha_{0}+\beta_{1} * P_{R O F_{i t-1}}+\beta_{2} * G D P_{i t}+\beta_{3} * I R_{i t}+\beta_{4} * I N F_{i t}+\beta_{5} * U N_{i t}+\beta_{6} * G F C F_{i t}+\beta_{7} \\
* E X_{i t}+\varepsilon_{i t}
\end{gathered}
$$

where the dependent variable is profitability (PROF), which is gradually represented by ROA, ROE and ROS indicators. This variable indicates the profitability for the $i$-th number of companies in a given economy in a particular sector during the period t (2010-2018). The independent variables on the right side of the equation are the individual determinants (GDP, IR, INF, UN, GFCF). At the same time, on this side we can find the constant $\alpha$ and the random component $\varepsilon$, which contains other determinants of profitability, which are not dealt with in this research, but affect the level of profitability. The last variable on this side mentions the delayed value of the dependent variable several times. This is an annual delay.

\subsection{Variables}

Depending on the method used, variables can be divided into dependent and independent. The dependent variable can be represented by several different indicators. In the studies mentioned in the literature search, the indicators ROA, ROAA, ROAE, ROE, net interest margin are often used. Given that these studies often dealt with the banking sector, not all indicators are suitable for traditional industries. With this in mind, the ROA, ROE and ROS indicators were chosen for this research. Return on assets is the ratio of profit before tax and interest and total assets. Return on equity is the share of profit after taxes. Return on sales is the ratio of profit before tax and interest and sales.

Independent variables are represented by selected determinants that should affect profitability. As mentioned in earlier sections, this research focuses on the determinants of the company's external environment. Independent variables are specifically in the form of the rate of GDP growth at market prices, basic interest rate of the economy (IR), inflation rate (INF), unemployment rate (UN) and gross fixed capital formation (GFCF).

\section{Results and discussion}

Figures 3, 4 and 5 contain the results of the GMM method for companies, which are divided according to the dependent variable, which were successively the indicators ROA, ROE and ROS. There were eight selected economies. At first glance, it is clear that not a single figure includes results for all determinants and all economies. The reason is that the models did not pass the Sargan test, their values were less than 0.05 , and their results would not be reliable.

Before we begin the interpretation of the results, it is possible to comment on the results for the lagged value of profitability, which is always in the first column and at the same time the coefficients for gross fixed capital formation in the last column. The coefficients for both variables are low, even very low for gross fixed capital formation, and therefore we cannot talk here about the influence, but rather about the direction that these variables show us. For both variables, the positive impact on the level of profitability equally prevails. It follows that if the companies were profitable in the past, it could still be in the following period. Gross fixed capital formation is related to the business cycle and the investment cycle. If companies created value in the previous period, it should continue to do so in the following period. 
The results will be analysed for individual subsectors and individual economies within these subsectors. Due to the number of results, it is not possible to analyze all of them in the possibilities of this article, and therefore the comments will focus mainly on the variables with the greatest influence in the given economy.

The first subsector is 411 - development of building projects. Czech companies were most affected by inflation, which affected them positively, as did GDP. In the Czech Republic, the inflation rate could reduce already low interest rates, which in real terms could be very low, giving companies space for debt financing, which increased their profitability. According to the assumptions, Slovak, Austrian and Bulgarian companies were negatively affected by the basic interest rate, which had the greatest influence on the level of profitability in these companies. The explanation is simple: throughout the period under review, the central banks of these economies have been lowering interest rates, which have even been zero for the last three years. This fact means very low costs for the acquisition of external resources. The profitability of Hungarian and Romanian companies was most affected by economic developments, which had a positive effect in Hungary and a negative effect in Romania. Despite the fact that Romanian construction companies grew sales and GDP grew at a respectable rate throughout the period under review, net profit was constantly negative except in 2016. The negativity was reflected in the ROE indicator, which affected the resulting impact. The Hungarian economy also grew significantly, which was reflected in growing sales and profits. The level of profitability of Polish and Slovenian companies was mostly affected by the unemployment rate; in Poland negatively, while in Slovenia positively. This discrepancy is interesting, as in both economies the unemployment rate developed similarly until 2013 it increased and then decreased. Unexpected positive impact in the case of Slovenian companies could be helped by fluctuating sales, which grew for one year, then fell, then rose again, etc. At the same time, profit before tax was negative in 2012, 2014, 2015 and 2016, which could have had an effect.

Subsector 412 - construction of residential and non-residential buildings revealed the following relationships. The development of the economy had a positive impact on the level of profitability of Slovak and Romanian companies. Both economies grew on average $3 \%$ year-on-year, as a result of which their profits also grew. The unemployment rate for Austrian companies played a key role, fluctuating around $5.2 \%$ over the period under review. Unfortunately, the companies in this subsector did not grow much profit, which could have affected the resulting positive impact of this variable. Slovenian companies were most affected by the inflation rate, and positively. The rate of inflation may have reduced already low interest rates, which in real terms could have been very low, giving companies room for debt financing that increased their profitability. The remaining companies were significantly affected by the interest rate, with Czech companies having a positive effect and the remaining companies having a negative effect. The negative for Polish and Hungarian companies is justified, as interest rates in these economies fell sharply during the period under review. In Bulgaria, the interest rate was at or close to zero for virtually the entire period under review, which brings the possibility of very cheap debt financing, which can bring us additional profit. The positive effect of Czech companies is unexpected, as interest rates in this economy were also low. However, during the period considered, profit before tax decreased, which may have affected the resulting effect.

Within subsector 421 - construction of roads and railways, Hungarian companies are negatively affected by GDP growth, which is unexpected given the growth rate of $2.5 \%$ yearon-year and profit before tax grew significantly except 2016 and sales also grew significantly 
except 2016 and 2017. Romanian and Austrian companies were most affected by the unemployment rate - negatively in Austria, positively in Romania. The positive relationship is special, but justified by a significant decline in pre-tax profit during the period under review, even with the current decline in unemployment. The remaining companies were affected by the interest rate, where in the Czech Republic, Slovakia and Slovenia the effect was positive, and vice versa in Bulgaria and Poland. In the first three economies, interest rates were very low, so it is difficult to find an explanation. Czech companies fluctuated their pretax profit, which declined in 2011, 2012, 2013, 2016, 2017 and 2018, which may have caused the impact. Also, in the remaining two economies, profit before tax or profit after tax fluctuated and decreased according to the indicator, but the movements were not as significant as in the case of Czech companies, but even that was enough for the positive impact of the interest rate on profitability. The negative coefficient for Polish companies is justified, as the interest rate decreased significantly during the period under review. In Bulgaria, the interest rate was at or close to zero for virtually the entire period under review, leading to the possibility of very cheap debt financing and the possibility of additional profits.

The results for subsector 422 - construction of utility projects for Czech, Slovak, Polish, Slovenian, Bulgarian and Romanian companies are identical to the results for subsector 411 in the previous paragraph. For Austrian companies, the development of the economy, which was not bad, played a key role, and therefore the resulting influence is also positive. Hungarian companies were negatively affected by the unemployment rate, which was over $10 \%$ in the first half of the period under review, which is a high value. Although less than $4 \%$ at the end of the period, the first half of the period clearly had a greater effect on the resulting impact.

Subsector 429 - construction of other civil engineering projects reported the following results. The level of profitability of Slovak, Polish, Hungarian, Austrian and Romanian companies was most affected by the interest rate, which had a negative effect on profitability. The Slovak and Austrian interest rates have undergone the same development with regard to euro area membership and have fallen to zero over the last three years. However, even at the beginning of the period it was not high, reaching $1 \%$. The case of interest rate developments in Poland, Hungary and Romania is quite different. In the period 2010/2011, rates reached their peaks $4.5 \%$ in Poland, $7 \%$ in Hungary and $6.25 \%$ in Romania. However, for the rest of the period under review, rates fell sharply to $1.5 \%$ in Poland, $0.9 \%$ in Hungary and $2.5 \%$ in Romania. This marked decline means what Slovak and Austrian companies do; thus, cheaper debt sources of financing that can generate additional profitability for businesses. Bulgarian and Slovenian companies were positively affected by GDP developments, as expected. The economy grew on average in both countries at around $2 \%$ per year, which also grew the sales and profits of companies in these economies. Czech companies were negatively affected by the inflation rate the most. The deviation from the assumptions can be explained by the fact that during the period under review, profit after tax fluctuated significantly, which in 2011, 2014, 2016 and 2018 decreased significantly compared to previous years. These fluctuations could affect the resulting impact. 
Figure 3: GMM model for indicator ROA

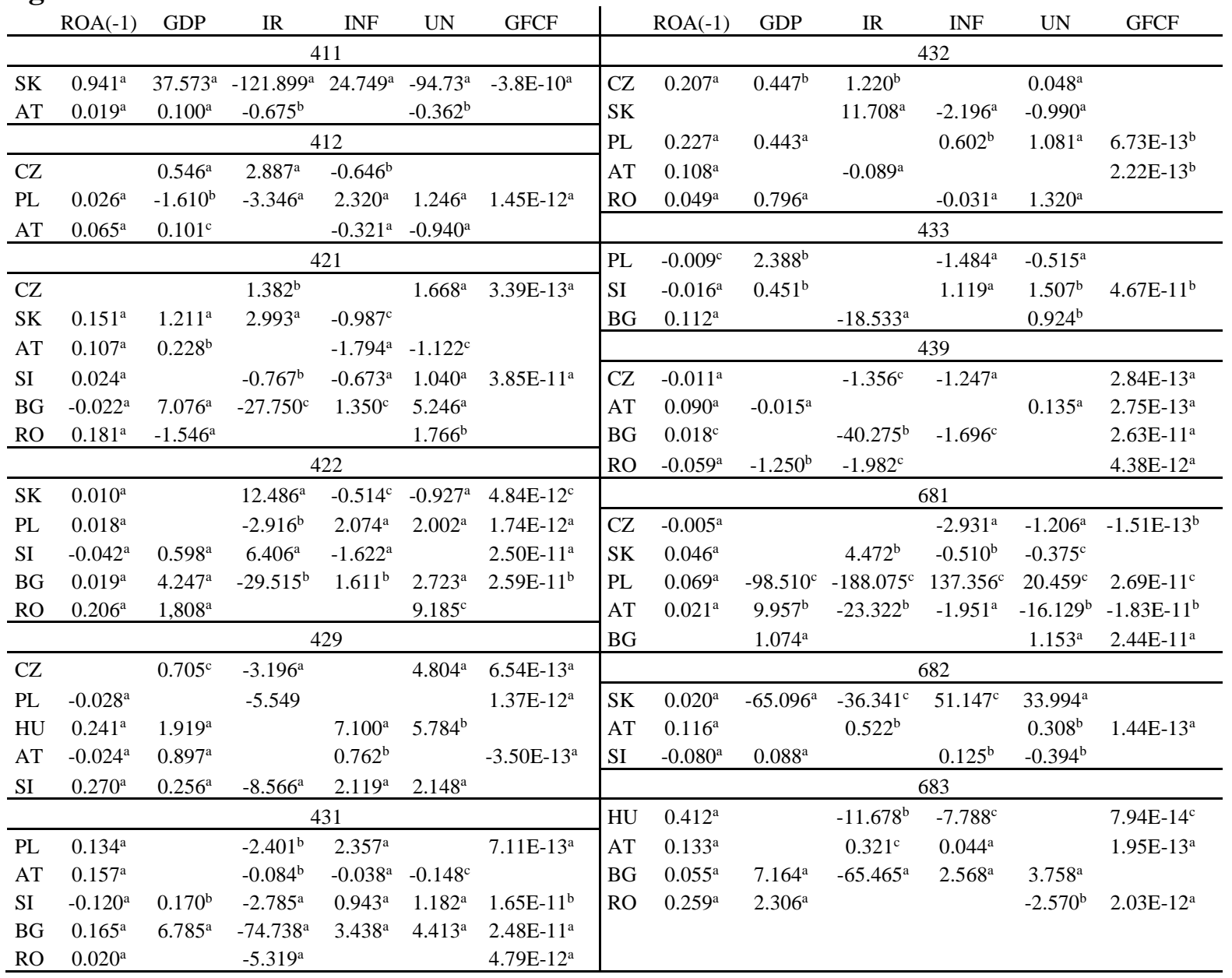

Source: author's calculations based on data from Orbis database Symbols: ${ }^{\mathrm{a}},{ }^{\mathrm{b}}$ and ${ }^{\mathrm{c}}$ indicate significance at $1 \%, 5 \%$, and $10 \%$.

According to the results, the clear factor that affected the level of profitability of companies belonging to subsector 431 - demolition and site preparation is the interest rate, which affected all companies except Austrian ones. In all companies, this variable had a negative impact. The development of interest rates in these economies has already been mentioned several times in the previous paragraphs, so there is no need to repeat it several times. The negative impact of the unemployment rate on the profitability of Austrian companies may be due to the relatively low unemployment rate, which fluctuated around $5.3 \%$ during the period.

Somewhat special results, which deviated from the expected impacts, are in subsector 432 electrical, plumbing and other construction installation activities. Polish and Romanian companies were most positively affected by economic development. It is not surprising that the Polish economy did not decline even once during the period under review, making it one of the few such economies in the world. It grew at an average rate of $3.5 \%$ per year. Although the Romanian economy contracted in 2010 due to the financial crisis, it grew by around $3.8 \%$ per year for the rest of the period. As a result of such high GDP growth rates, the growth in corporate profitability is not surprising. In Hungary, the rate of inflation, which had a positive effect on companies, played a key role, further helping to reduce real interest rates, which fell sharply over the period. The impact of the interest rate is a change that has worked very unexpectedly and even inexplicably in certain economies. Austrian and Bulgarian companies were expected to be negatively affected. As mentioned, several times, 
these economies had low interest rates, which created an ideal environment in the use of external sources of financing, which can help higher profitability. However, the positive impact on Czech, Slovak and Slovenian companies is hard to find. Interest rates were low, ROA and ROS were very good, companies were extremely profitable, so a positive relationship is really unexpected.

Figure 4: GMM model for indicator ROE

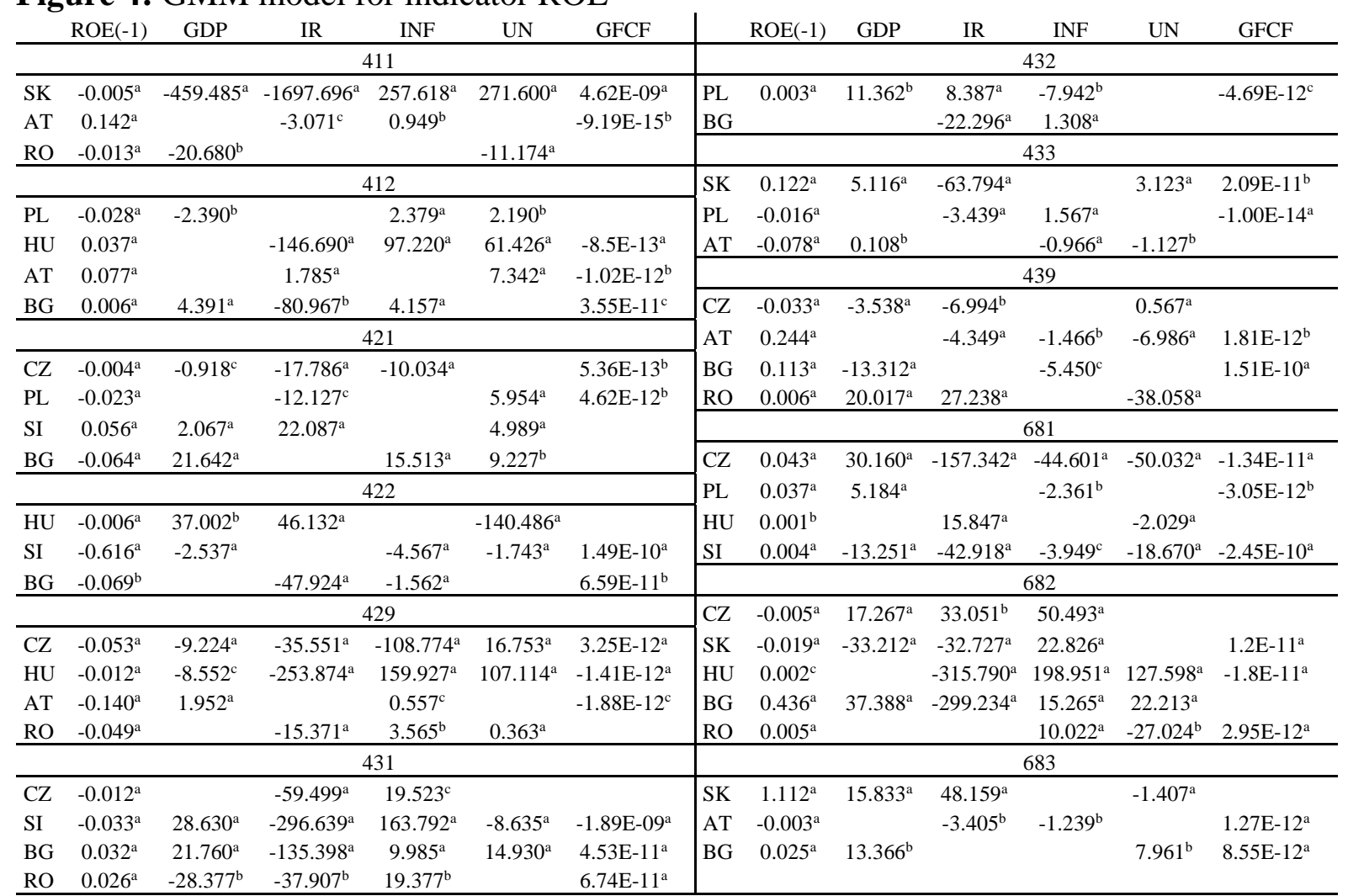

Source: author's calculations based on data from Orbis database

Symbols: ${ }^{\mathrm{a}},{ }^{\mathrm{b}}$ and ${ }^{\mathrm{c}}$ indicate significance at $1 \%, 5 \%$, and $10 \%$.

As in the previous subsector 432, in subsector 433 - building completion and finishing, the unexpected positive impact of the interest rate on the level of profitability of Czech and Slovenian companies is unexpected. Again, neither sales nor profit before tax show significant changes, on the contrary, it is more or less constantly growing. On the other hand, the negative impact of the interest rate on the profitability of Slovak, Polish and Bulgarian companies is more than expected and explained several times. Romanian and Austrian companies were most affected by the unemployment rate, in a negative way. In both economies, unemployment fluctuated and fell towards the end of the period. In Hungary, the rate of inflation, which had a positive effect on companies, played a key role, further helping to reduce real interest rates, which fell sharply over the period.

The last subsector belonging to the construction industry is 439 - other specialized construction activities. All variables except gross fixed capital formation had an impact here, and by the end all relations are as expected, and in addition they have been explained several times in the previous paragraphs. The most significant negative impact of the interest rate was in Czech, Polish and Bulgarian companies. Slovak companies were significantly positively influenced by the development of the economy. In Hungary and Slovenia, the positive impact of the inflation rate played a key role and the unemployment rate negatively affected the level of profitability in Austrian and Romanian companies. 
Figure 5: GMM model for indicator ROE

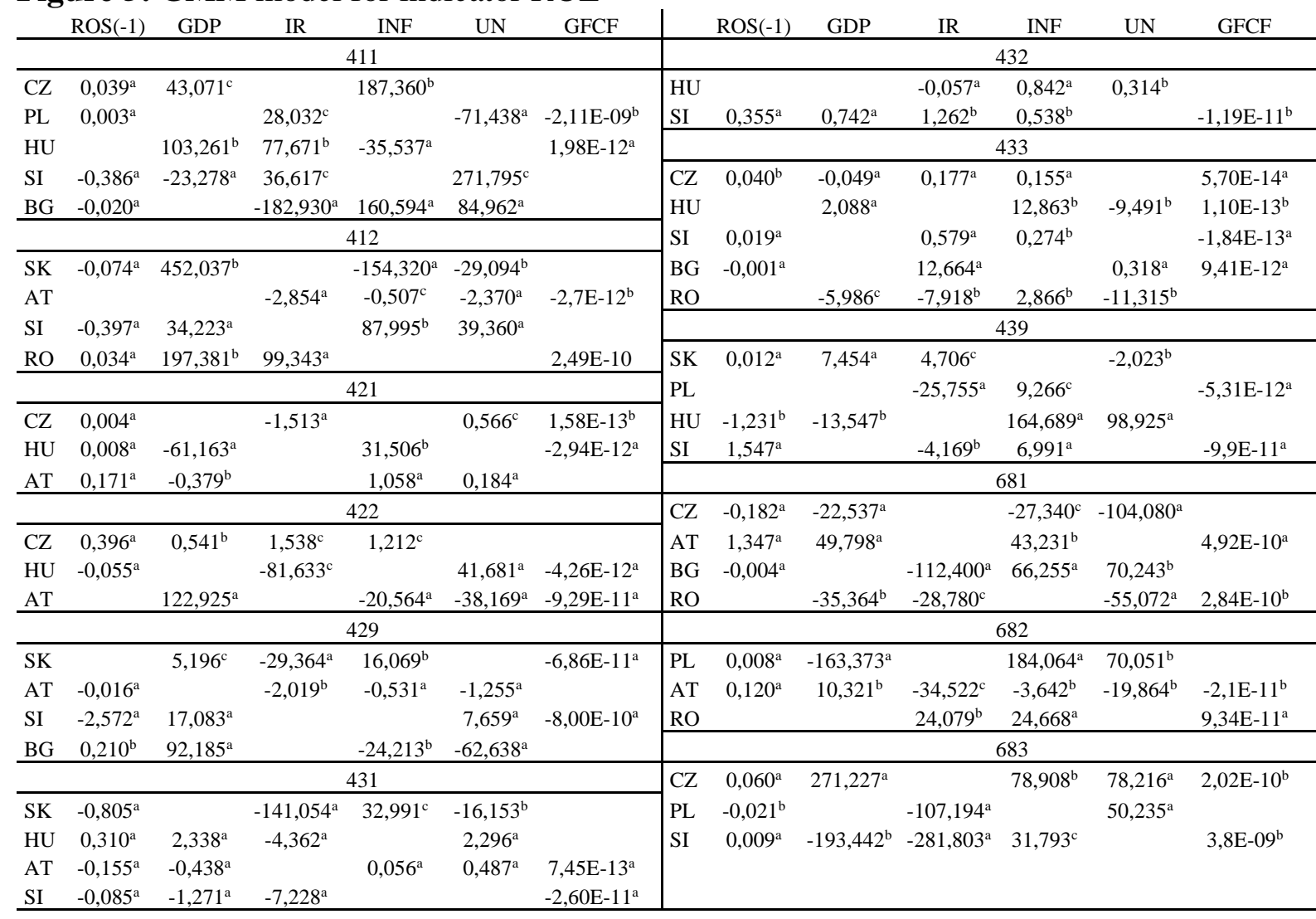

Source: author's calculations based on data from Orbis database

Symbols: ${ }^{\mathrm{a}},{ }^{\mathrm{b}}$ and ${ }^{\mathrm{c}}$ indicate significance at $1 \%, 5 \%$, and $10 \%$.

Subsector 681 - buying and selling of own real estate was most affected by the interest rate. In Czech, Polish, Slovenian and Bulgarian companies, this effect was negative with regard to low interest rates during the period under review in these economies. On the other hand, Hungarian and Slovak societies were positively affected. The development of the ROA indicator for Slovak companies fluctuated with very low values. and even in 2015 and 2016, the indicator was negative as companies together generated a negative pre-tax profit. The ROE for Hungarian companies for the first five years was very low and negative in 2010 and 2013. On the contrary, the last five have grown to over $5 \%$. Here the indicator was fluctuated profit after tax, which was in negative in 2010-2014. Austrian companies were positively affected by the development of the economy, which did not suffer from major problems during the period, as a result of which sales and profits grew. Romanian companies were most affected by the unemployment rate, which negatively affected these companies.

Subsector 682 - renting and operating of own or leased real estate is again affected by all four variables (except gross fixed capital formation). Czech and Polish companies were able to take advantage of the positive impact of the inflation rate, which reduced real interest rates, which in the Czech Republic, for example, were already so low. Slovenian and Romanian companies were able to take advantage of declining unemployment rates, which resulted in increasing profitability of these companies. Hungarian, Bulgarian and Austrian companies were able to take advantage of cheaper debt financing due to low interest rates, which, given the negative ties, could increase companies' profitability. Slovak companies were negatively affected by the development of the economy, despite the fact that the Slovak economy grew by an average of $3.1 \%$ per year. Unfortunately, the profit after tax is to blame here, which 
was even negative in 2013, 2014, and especially in the first half of the period under review, it was quite unstable and very volatile.

As in most subsectors, subsector 683 - real estate activities on a fee or contract basis is no exception and the effects of the interest rate on the level of profitability prevail. In Polish, Hungarian, Austrian, Slovenian and Bulgarian, this effect is negative and has been explained several times. The impact on Slovak companies is positive. The explanation is the negative profit after tax in the period 2010-2015. Czech companies were positively affected by the development of the economy, which, in addition to declines in 2012/2013, grew by about $3.1 \%$ per year. Romanian companies were able to take advantage of declining unemployment rates, which resulted in increasing profitability of these companies

\section{Conclusion}

This research focused on the profitability of companies in the construction and real estate activities industries. These sectors were divided into twelve sub-sectors, for which the impact of selected determinants on the level of profitability was determined. The companies came from eight economies of Central and Eastern Europe, which belong to the expanded Visegrád Group. Specifically, these were the Czech Republic, Slovakia, Poland, Hungary, Austria, Bulgaria, Slovenia, Romania. The determinants were as follows: GDP growth rate, inflation rate, basic interest rate, unemployment rate, gross fixed capital formation. The influence of these determinants was tested on a total of 89,544 companies in the period 2010-2018. The aim of the research was to use Generalized Method of Moments to find out whether selected determinants affect corporate profitability or not. Within this goal, four research questions were formulated:

1. Economic development and gross fixed capital formation should have a positive impact on the level of profitability.

2. The inflation rate could also have a positive effect on the level of profitability.

3. The reference interest rate should have a negative impact on the level of profitability.

4. The unemployment rate should also negatively affect the level of profitability.

There are a huge number of results. In the Results chapter, the determinants that had the greatest influence on the level of profitability in individual subsectors and economies were discussed. There are several conclusions. If we look at the individual economies and the strongest subsectors, then the following follows:

- The Czech Republic and Slovakia are dominated by subsector 682 - renting and operating of own or leased real estate, which is positively affected by the inflation rate (CZ) and the negative impact of economic development (SK).

- In Poland, Slovenia, Romania and Bulgaria, subsector 412 - construction of residential and non-residential buildings, predominates, which is negatively affected by interest rates (PL, BG) and positively affected by inflation rates (SI) and economic development $(\mathrm{RO})$.

- In Hungary, companies from subsector 681 - buying and selling of own real estate, predominate, whose profitability is positively affected by interest rates.

- In Austria, most companies come from subsector 683 - real estate activities on a fee or contract basis, the profitability of which is negatively affected by interest rates.

If we look at the results from the point of view of individual subsectors, in eight out of twelve the influence of the interest rate on the level of profitability prevails, and at the same time in the remaining five no factor outweighs the results for interest rates. Unfortunately, only their results do not have a majority. 
Based on this summary, we can say that the main conclusion of this research is that the greatest influence on the level of profitability in the construction and real estate activities sectors has the basic interest rates of individual economies and that this effect is mostly negative. This means that as rates fall, profitability should increase, as companies could benefit from cheaper debt financing, which could generate additional profitability for them. The resulting impact is not surprising, as in the Czech Republic, Slovakia, Austria, Slovenia and Bulgaria the values of basic interest rates were very low, often reaching zero. Although interest rates were higher in Poland, Romania and Hungary at the beginning of the period under review, they fell sharply during the period under review, making foreign sources of financing more attractive.

What does such a finding mean for companies? Companies and designated staff should focus on the various macroeconomic forecasts and statements of the members of the bank boards of the respective central banks. Above all, they should focus on information about interest rate cuts and, as part of this, do a brief analysis of profitability and incorporate the scenario of "what if we borrowed, what would it mean for us in terms of profitability?".

\section{Acknowledgement}

This article was supported by SGF/16/2020 Influence of selected internal and macroeconomic determinants on financial structure of companies in selected countries of Central and Eastern Europe.

\section{References}

[1] AKOTEY, J. O., F. G. SACKEY and L. AMOAH, 2013. The financial performance of life insurance companies in Ghana. Journal of Risk Finance, 14(3), 286-302. ISSN 15265943.

[2] ALBERTAZZI, U. and L. GAMBACORTA, 2009. Bank profitability and the business cycle. Journal of Finance Stability, 5(4), 393-409. ISSN 1572-3089.

[3] AliagA-DiAZ, R. and M. P. OLIVERO, 2010. The Cyclicality of Price-Cost Margins in Banking: An Empirical Analysis of its Determinants. Economic Inquiry, 49(1), 26-46. ISSN 1465-7295.

[4] ALMEIDA, F. and J. A. DIVINO, 2015. Determinants of the banking spread in the Brazilian economy: The role of micro and macroeconomic factors. International Review of Economics \& Finance, 40, 29-39. ISSN 1059-0560.

[5] ARELLANO, M. and S. BOND, 1991. Some Tests of Specification for Panel Data: Monte Carlo Evidence and an Application to Employment Equations. Review of Economic Studies, 58(2), 277-297. ISSN 1467-937X.

[6] ATHANASOGLOU, P. P., S. N. BRISSIMIS and M. D. DELIS, 2008. Bank-specific, industry-specific and macroeconomic determinants of bank profitability. Journal of International Financial Markets, Institutions and Money, 18(2), 121-136. ISSN 10424431.

[7] BASHIR, A. H., 2003. Determinants of profitability in Islamic banks: Some evidence from the Middle East. Islamic Economic Studies, 11(1), 31-57. ISSN 1319-1616.

[8] BIKKER, J. and H. HU, 2002. Cyclical patterns in profits, provisioning and lending of banks and procyclicality of the new Basel capital requirements. Banca Nazionale del Lavoro Quarterly Review, 55(221), 143-175. 
[9] BOURKE, P., 1989. Concentration and other determinants of bank profitability in Europe, North America and Australia. Journal of Banking and Finance, 13, 65-79. ISSN 0378-4266.

[10] CHOUIKH, A. and Y. BLAGUI, 2017. The Determinants of Bank Performance: The Case of Tunisian Listed Banks. Journal of Finance and Accounting, 5(2), 53-60. ISSN 2333-8857.

[11] CLAESSENS, S., A. DEMIRGÜÇ-KUNT and H. HUIZINGA, 1998. How Does Foreign Entry Affect the Domestic Banking Market? Policy Research Working Paper No. 1918.

[12] ĆURAK, M., K. POPOSKI and S. PEPUR, 2012. Profitability Determinants of the Macedonian Banking Sector in Changing Environment. Procedia - Social and Behavioral Sciences, 44, 406-416. ISSN 1877-0428.

[13] DEMIRGÜÇ-KUNT, A. and H. HUIZINGA, 1998. Determinants of Commercial Bank Interest Margins and Profitability: Some International Evidence. The World Bank Economic Review, 13(2), 379-408. ISSN 1564-698X.

[14] DIETRICH, A. and G. WANZENRIED, 2011. Determinants of bank profitability before and during the crisis: Evidence from Switzerland. Journal of International Financial Markets, Institutions and Money, 21, 307-327. ISSN 1042-4431.

[15] DIETRICH, A. and G. WANZENRIED, 2014. The determinants of commercial banking profitability in low-, middle-, and high-income countries. The Quarterly Review of Economics and Finance, 54, 337-354. ISSN 1062-9769.

[16] DJALILOV, K. and J. PIESSE, 2016. Determinants of bank profitability in transition countries: What matters most? Research in International Business and Finance, 38, 6982. ISSN 0275-5319.

[17] FLAMINI, V., C. MCDONALD and L. SCHUMACHER, 2009. The Determinants of Commercial Bank Profitability in Sub-Saharan Africa. IMF Working paper No. 15.

[18] GAGANIS, CH., I. HASAN and F. PASIOURAS, 2013. Efficiency and Stock Returns: Evidence From the Insurance Industry. Journal of Productivity Analysis, 40, 429-442. ISSN 1573-0441.

[19] GODDARD, J., P. MOLYNEUX and J. O. S. WILSON, 2004. The profitability of european banks: a cross-sectional and dynamic panel analysis. The Manchester School, 72(3), 363-381. ISSN 1467-9957.

[20] JAGANNATHAN, R., G. SKOULAKIS and Z. WANG, 2002. Generalized Method of Moments: Applications in Finance, Journal of Business and Economic Statistics, 20(4), 470-481.

[21] KILLINS, R. N., 2020. Firm-specific, industry-specific and macroeconomic factors of life insurers' profitability: Evidence from Canada. North American Journal of Economics and Finance, 51. ISSN 1062-9408.

[22] KOŠAK, M. and M. ČOK, 2013. Ownership Structure and Profitability of the Banking Sector: The Evidence from the SEE-6 Region. Proceedings of Rijeka Faculty of Economics, Journal of Economics and Business, 26(1), 93-112. ISSN 1846-7520.

[23] LE, T. D. and T. NGO, 2020. The determinants of bank profitability: A cross-country analysis. Central Bank Review, 20, 65-73. ISSN 1303-0701. 
[24] MARTINS, A. M., A. P. SERRA and S. STEVENSON, 2019. Determinants of real estate bank profitability. Research in International Business and Finance, 49, 282-300. ISSN 0275-5319.

[25] MIRZAEI, A., M. TOMOE and G. LIU, 2013. Does market structure matter on banks' profitability and stability? Emerging vs. advanced economies. Journal of Banking \& Finance, 37, 2920-2937. ISSN 0378-4266.

[26] MOLYNEUX, P. and J. THORNTON, 1992. Determinants of European bank profitability: A note. Journal of Banking \& Finance, 16(6), 1173-1178. ISSN 0378-4266.

[27] PERRY, P., 1992. Do Banks Gain or Lose from Inflation? Journal of Retail Banking, 14(2), 25-30. ISSN 0195-2064.

[28] PERVAN, M., I. PERVAN and A. GUADAGNINO, 2010. Market Structure and Profitability of Croatian Commercial Banks. The Business Review, 20(1), 209-216. ISSN 1553-5827.

[29] PRŮCHA, I. R., 2014. Instrumental Variables/Method of Moments Estimation. In Fisher, M. M. \& P. Nijkamp (Rd.), Handbook of Regional Science. Heidelberg: Springer, s. 1597-1617. ISBN 978-3-642-23429-3.

[30] REVELL, J., 1979. Inflation \& financial institutions. London: Financial Times Ltd. ISBN 9780903199308.

[31] ROODMAN, D., 2009. How to do xtabond2: An introduction to difference and system GMM in Stata, The Stata Journal, 9(1), 86-136. ISSN 1536-8734.

[32] SAONA, P., 2016. Intra- and Extra-bank Determinants of Latin American Banks' Profitability. International Review of Economics \& Finance, 45, 197-214. ISSN 10590560 .

[33] SUFIAN, F. and R. R. CHONG, 2008. Determinants of Bank Profitability in a Developing Economy: Empirical Evidence from the Philippines. Asian Academy of Management Journal of Accounting and Finance, 4(2), 91-112. ISSN 2180-4192.

[34] TAN, Y. A. and CH. FLOROS, 2012. Bank profitability and inflation: The case of China. Journal of Economic Studies, 39(6), 675-696. ISSN 0144-3585.

[35] TRUJILlO-PONCE, A., 2013. What Determines the Profitability of Banks? Evidence from Spain. Accounting \& Finance, 53(2), 561-586. ISSN 1467-629X.

[36] ULLAH, S. et al., 2018. Dealing with Endogeneity Bias: The Generalized Methods of Moments (GMM) for panel data, Industrial Marketing Management, 71, 69-78. ISSN 0019-8501.

[37] VERA-GILCES, P. et al., 2020. A look inside banking profitability: Evidence from a dollarized emerging country. The Quarterly Review of Economics and Finance, 75, 147166. ISSN 1062-9769.

[38] ZUIDBERG, J., 2017. Exploring the determinants for airport profitability: Traffic characteristics, low-cost carriers, seasonality and cost efficiency. Transportation Research Part A, 101, 61-72. ISSN 0965-8564. 